Gepubliceerd in: Tijdschrift voor Criminologie, jg. 60(1), 2018, pp. 97-110

\title{
KRONIEK
}

\section{ECONOMISCHE THEORIEVORMING OVER MISDAAD EN STRAF, VIJFTIG JAAR NA BECKER}

\author{
B.C.J. van Velthoven*
}

\section{Inleiding}

Eerdere kronieken in dit tijdschrift hebben aandacht besteed aan het empirische economische onderzoek op het terrein van misdaad en straf. In deze kroniek wil ik stilstaan bij de theorievorming. Dit leek mij een goed moment omdat Gary Becker's artikel over de Economics of Crime and Punishment in 1968 werd gepubliceerd, nu vijftig jaar geleden.

Met dat artikel werd de basis gelegd voor een nieuw vakgebied binnen de economie. Weliswaar hadden in een ver verleden Beccaria (1764) en Bentham (1789) verwante analyses het licht doen zien, maar die waren - in ieder geval binnen de economische wetenschap - in de vergetelheid geraakt. En meer recent hadden economische onderzoekers zich wel incidenteel gebogen over relevante deelthema's; zie bijvoorbeeld Fleisher (1963). Maar die studies misten een breder theoretisch kader. Dat theoretische kader werd aangedragen door Becker in zijn grensverleggende artikel uit 1968. Dat artikel ontleent zijn betekenis verder aan het feit dat het twee vliegen in een klap slaat. In de eerste plaats geeft Becker een verklaring voor de omvang van de criminaliteit in de samenleving op grond van de rationele-keuzetheorie. Vervolgens gebruikt hij die verklaring als aangrijpingspunt voor het ontwikkelen van een optimaal criminaliteitsbeleid op basis van een maatschappelijke kosten-batenanalyse. In de voetsporen van Becker heeft de bestudering van criminaliteitsvraagstukken onder economen inmiddels een grote vlucht genomen. De betekenis van Becker's artikel wordt onderstreept door het indrukwekkende aantal van ruim 15.000 citaties, ${ }^{1}$ een aantal dat nog elke dag groeit.

In dat licht is het buitengewoon opmerkelijk dat twee recente, elk ruim 500 pagina's tellende overzichten van de criminologische theorievorming (Lilly e.a., 2015; Piquero, 2016) het niet de moeite waard vinden om zijn naam überhaupt te noemen. Voor zover in die overzichtswerken wordt verwezen naar de economische literatuur blijft dat beperkt tot enkele empirische studies met betrekking tot het effect van afschrikking. Aandacht voor rationelekeuze-overwegingen blijft beperkt tot witteboordencriminaliteit en een kritische bespreking van het werk van Cornish \& Clarke. De potentiële betekenis van maatschappelijke kostenbatenanalyse komt in het geheel niet ter sprake.

Die discrepantie in de waardering van de economische theorievorming over misdaad en straf, zoals in de kern neergelegd door Becker (1968) en sindsdien in verschillende richtingen verder ontwikkeld, is een goede reden om nader stil te staan bij de uitgangspunten, betekenis en beperkingen van die economische theorievorming.

\section{Becker's theorie}

Becker was een representant van de neoklassieke economische theorie. Die theorie gaat uit

\footnotetext{
* Als universitair hoofddocent rechtseconomie verbonden aan de Juridische Faculteit in Leiden. Met dank aan drs. B.L. Terpstra voor commentaar op een eerdere versie.

1 Bron: Google Scholar.
} 
van methodologisch individualisme, het idee dat maatschappelijke verschijnselen kunnen worden verklaard door het gedrag van actoren te aggregeren. Afzonderlijke actoren worden verondersteld (min of meer) stabiele voorkeuren te hebben en binnen de grenzen van hun mogelijkheden rationele keuzes te maken. Vervolgens wordt bekeken of en hoe de interactie op geaggregeerd niveau tot een evenwichtssituatie leidt waarin het gedrag van de verschillende actoren wordt gecoördineerd.

De bekendste toepassing van deze theorie betreft de werking van de markten voor consumptiegoederen. De marktvraag en het marktaanbod worden gezien als aggregaten van respectievelijk de vraag van de afzonderlijke nutsmaximaliserende consumenten en het aanbod van de afzonderlijke winstmaximaliserende producenten. De interactie tussen de marktvraag en het marktaanbod geeft vervolgens een verklaring voor de verhandelde hoeveelheid en de prijs op de markt.

Dat algemene model wordt door economen in nadere analyses van de werking van markten op twee zeer uiteenlopende manieren gebruikt. In de eerste plaats is er een strikt theoretische onderzoekslijn, waarin aan de hand van vaak complexe wiskundige analyses wordt nagegaan onder welke voorwaarden marktwerking tot een maatschappelijk optimale allocatie van schaarse middelen leidt. In deze lijn komen we algemene evenwichtsmodellen tegen, met veronderstellingen als consistent geordende voorkeuren, ieder op en voor zichzelf, perfecte en kosteloze informatie en volledige mededinging. Dat wil niet zeggen dat economen al deze veronderstellingen zonder meer onderschrijven, integendeel. In de praktijk zal veelal niet volledig aan al deze voorwaarden zijn voldaan, zodat er in meer of mindere mate sprake is van marktfalen. Hoe ernstig de problemen van marktfalen zijn, en hoe ze aangepakt kunnen worden, is dan ook een belangrijk onderwerp van studie binnen de economie.

In de tweede plaats is er een zeker zo belangrijke toegepaste onderzoekslijn, waarin wordt onderzocht welke factoren (mede)verantwoordelijk zijn voor de verschijnselen op concrete markten. In deze lijn wordt empirisch onderzoek gedaan naar consumentengedrag, mededingingsvraagstukken, arbeidsaanbodbeslissingen enz. Van geval tot geval wordt bekeken binnen welke mogelijkheden en restricties de betrokken partijen opereren en welke economische prikkels aan de orde zijn in de vorm van materiële en immateriële baten en kosten. Verder wordt onderkend dat partijen in de praktijk kunnen verschillen in hun voorkeuren, informatie(kosten), rationaliteit e.d. Het empirische onderzoek vormt een toets op de theorie, in de zin dat duidelijk wordt of en in hoeverre prikkels en restricties een rol spelen. Datzelfde empirische onderzoek geeft ook inzicht in de invloed van achtergrondvariabelen.

Becker was doordrongen van de gedachte dat de economische benadering niet beperkt hoeft te blijven tot het domein van de marktwerking. Hij heeft deze ook toegepast op andere sociale vraagstukken zoals discriminatie, gezinsvorming en criminaliteit. ${ }^{2}$

In Becker (1968) geeft hij in de eerste plaats een verklaring voor de omvang van de criminaliteit. Uitgaande van de economische visie op keuzegedrag veronderstelt hij dat iemand een delict pleegt als het verwachte nut daarvan, de bijdrage aan het persoonlijke welbevinden, groter is dan het nut van de alternatieve, legale aanwending van de beschikbare middelen. Als sommige mensen crimineel gedrag vertonen, is dat dan ook niet omdat hun elementaire motivatie anders is, maar omdat hun baten en kosten anders zijn.

De afweging van een persoon die een delict overweegt kan zichtbaar worden gemaakt met een formule. Stel dat $U_{j}$ de nutsfunctie van persoon $j$ is; deze functie legt het verband tussen de beschikbare middelen en het nutsniveau van de persoon. De legale opbrengsten van de betrokkene worden aangeduid met $L_{j}$, de netto opbrengst (monetair en psychisch) van crimineel handelen met $C_{j}$. Verder staat $p_{j}$ voor de kans dat het delict wordt opgespoord en

2 Op grond van dat werk werd hem in 1992 de Nobelprijs voor Economie toegekend. 
bestraft en $f_{j}$ voor de zwaarte van de sanctie. Het verwachte nut van crimineel gedrag, $E U_{j}$, wordt dan gegeven door de volgende formule:

$$
E U_{j}=\left(1-p_{j}\right) \cdot U_{j}\left(L_{j}+C_{j}\right)+p_{j} \cdot U_{j}\left(L_{j}+C_{j}-f_{j}\right) .
$$

De eerste component in het rechterlid geeft het nutsniveau van persoon $j$ als hij het delict pleegt en ongestraft blijft, gewogen met de kans dat hij vrijuit gaat; de tweede component geeft het nutsniveau als de persoon het delict pleegt en de sanctie $f_{j}$ moet ondergaan, gewogen met de kans dat hij tegen de lamp loopt. ${ }^{3}$ Crimineel gedrag is interessant voor persoon $j$ als het verwachte nut van het plegen van het delict, $E U_{j}$, groter is dan het nut als hij op het rechte pad blijft, $U_{j}\left(L_{j}\right)$. Duidelijk is dat naarmate de pakkans $p_{j}$ kleiner en de straf $f_{j}$ lichter is, het verwachte nut $E U_{j}$ groter uitvalt zodat crimineel gedrag per saldo aantrekkelijker is. Maar evenzeer is duidelijk dat de pakkans en de strafzwaarte niet de enige bepalende factoren zijn. Of crimineel gedrag voor de persoon per saldo de moeite waard is, hangt ook af van de gelegenheid tot en netto opbrengst van het delict, de legale opbrengsten, de beschikbare informatie, de specifieke vorm van de nutsfunctie en de mate van bewuste en doelgerichte rationaliteit.

Kortheidshalve vat Becker het aldus beredeneerde verband samen in de volgende functie:

$$
O_{j}=O_{j}\left(p_{j}, f_{j}, u_{j}\right)
$$

Volgens deze functie hangt $O j$, het aantal delicten van persoon $j$ binnen een bepaalde periode, af van $p_{j}$ en $f_{j}$, de pakkans en de strafzwaarte als instrumenten van het criminaliteitsbeleid, en van $u_{j}$, een containervariabele die alle andere invloeden weergeeft.

Om uit te komen bij de totale omvang van de criminaliteit, $O$, aggregeert Becker over alle relevante personen. Als optelsom is dat totaal in beginsel afhankelijk van alle afzonderlijke $p_{j}$, $f_{j}$ en $u_{j}$. Aannemelijk is dat die variabelen tussen personen niet onbelangrijk verschillen, vanwege verschillen in leeftijd, intelligentie, opvoeding, crimineel verleden enz. Het verband wordt echter aanzienlijk vereenvoudigd als $O$ bij benadering geschreven kan worden als een functie van de gemiddelde waarden, $p, f$ en $u$ :

$$
O=O(p, f, u)
$$

Op grond van het voorgaande kan worden aangenomen dat het verband tussen het aantal delicten enerzijds en de pakkans en de strafzwaarte anderzijds negatief is.

Deze verklaring van de omvang van de criminaliteit vormt voor Becker vervolgens de basis voor een afleiding van de maatschappelijk optimale aanpak van de criminaliteit. Daarbij hanteert hij het efficiëntiecriterium en weegt hij de netto schade van crimineel gedrag voor de samenleving af tegen de maatschappelijke kosten van criminaliteitsbestrijding. Instrumenten zijn de pakkans en de strafmaat; generale afschrikking staat dus centraal. Belangrijke conclusies zijn: (i) voor zover de middelen van delinquenten dat toestaan verdient het opleggen van een geldboete de voorkeur boven andere strafsoorten, omdat een boete slechts een geldtransfer is die bij executie niet of nauwelijks beslag legt op schaarse maatschappelijke middelen; (ii) een uitruil in de vorm van een verlaging van de pakkans en een evenredige

\footnotetext{
3 Wellicht ten overvloede wijs ik erop dat in de economische benadering aan immateriële belangen evenzeer betekenis toekomt als aan materiële. Letterlijk genomen veronderstelt vergelijking (1) dat alle immateriële elementen, zoals de psychische opbrengst van het delict of het psychische ongemak van een vrijheidsstraf, door de persoon op geld gewaardeerd kunnen worden. Iets algemener geformuleerd veronderstelt vergelijking (1) dat de persoon in staat is om een consistente afweging te maken van alle relevante baten en kosten, materieel èn immaterieel.
} 
verzwaring van de strafmaat kan maatschappelijk interessant zijn, vanwege een besparing op de opsporingskosten bij overigens gelijke afschrikkende werking; (iii) het is waarschijnlijk optimaal om niet alle delicten af te schrikken ('underdeterrence'), (a) omdat er delicten kunnen zijn die per saldo bijdragen aan de maatschappelijke welvaart ${ }^{4}$ en (b) omdat het voorkomen van de netto schade van delicten vanaf enig punt niet opweegt tegen de extra kosten van opsporing en bestraffing; (iv) in het optimum is de omvang van de criminaliteit gevoeliger voor veranderingen in de pakkans dan in de strafmaat, omdat delinquenten risicominnend ${ }^{5}$ zijn.

Samengevat volgt Becker's model van misdaad en straf in beginsel de opbouw van het economische model voor de werking van de markt: methodologisch individualisme rationele keuze - aggregeren. Daarbij gaat het Becker niet om de juistheid van de individuele afweging voor elke afzonderlijke burger, vergelijking (1), maar om de bruikbaarheid van de verklaring op maatschappelijk niveau, vergelijking (3). Die laatste vergelijking behoudt zijn relevantie als delinquenten onvolledig geïnformeerd en beperkt rationeel zijn.

Resteert de vraag of de interactie op geaggregeerd niveau tot een evenwicht leidt, waarin het gedrag van alle actoren consistent samenhangt. Op dat punt houdt Becker zich in zijn analyse van misdaad en straf op de vlakte. Hij lijkt impliciet te veronderstellen dat het feitelijke criminaliteitsbeleid van de overheid samenvalt met het door hem afgeleide maatschappelijk optimale beleid. Waarom dat zo zou zijn, laat hij in het midden; hij geeft geen theorie van de politieke besluitvorming ter rechtvaardiging.

\section{In de voetsporen van Becker}

Anders dan niet-economen soms lijken te denken, heeft de benadering op basis van rationeel keuzegedrag (vooralsnog) niet geresulteerd in één allesomvattende economische theorie, maar in een verzameling verwante deelmodellen voor afzonderlijke onderzoeksvragen. Dat geldt voor de analyse van de werking van markten; zie Rodrik (2015). Dat geldt ook voor de economie van misdaad en straf. In de theorievorming sinds 1968 kunnen grosso modo twee hoofdlijnen worden onderscheiden. Enerzijds proberen wiskundig onderlegde theoretici met abstracte modellen meer inzicht te krijgen in de optimale inrichting van het criminaliteitsbeleid. Deze onderzoekslijn kan normatief worden genoemd, omdat het streven naar maximale maatschappelijke welvaart, het efficiëntiecriterium, leidend is. ${ }^{6}$ Anderzijds zijn er statistisch onderlegde empirici die stukjes theorie (her)formuleren voor de afleiding van empirische voorspellingen, en aan de hand van data toetsen of de beredeneerde verbanden

\footnotetext{
4 Delicten zijn niet voor niets strafbaar gesteld. Het is dan ook aannemelijk dat delicten in het algemeen ten koste gaan van de maatschappelijke welvaart. Maar dat sluit niet uit dat er uitzonderingen zijn. Denk aan de arts die op weg naar een spoedgeval een snelheidsovertreding maakt. Of aan de klokkenluider die zijn ambtseed of geheimhoudingsplicht schendt om een misstand publiek te maken.

Een delinquent is risicominnend als hij van het dragen van risico als zodanig een kick krijgt die de nadelige gevolgen van de sanctie voor zijn persoonlijke welbevinden in meerdere of mindere mate compenseert. Een risicominnend persoon die ex ante zou kunnen kiezen tussen de zekerheid van een vaste sanctie en de onzekerheid van een bepaalde kans op een hoge(re) en een complementaire kans op een lage(re) straf met overigens dezelfde gemiddelde strafzwaarte, zou voor de onzekere tweede optie kiezen. Voor een risico-avers persoon geldt het omgekeerde. Die heeft een afkeer van het dragen van risico die de nadelige gevolgen van de sanctie voor zijn persoonlijke welbevinden in meerdere of mindere mate versterkt. Zie uitgebreider Van Velthoven (2017), 109-112.

6 Veel economen vinden overigens dat het gebruik van het efficiëntiecriterium niet echt normatief genoemd kan worden. Ze rekenen weliswaar in teleologische zin voor wat het gevolg is van toepassing van het criterium, maar zijn daarom nog niet van mening dat efficiëntie in de praktijk ook het (enige) relevante besliscriterium is. In hun visie is de uiteindelijke afweging aan de politiek. Zie daarentegen Kaplow \& Shavell (2002), die beargumenteren dat het efficiëntiecriterium inderdaad de voorkeur verdient boven (andere) criteria van rechtvaardigheid.
} 
zich in de werkelijkheid voordoen. Deze onderzoekslijn is positivistisch van aard. Aansluitend worden de bevindingen soms ingezet in een maatschappelijke kosten-batenanalyse, om te bepalen of een interventie die blijkt te werken maatschappelijk ook loont. In dat geval wordt weer het efficiëntiecriterium gehanteerd. Ik ga op beide onderzoekslijnen wat dieper in.

\subsection{Theorie van het optimale criminaliteitsbeleid}

In het optimale criminaliteitsbeleid volgens Becker (1968) dient de overheid zoveel mogelijk gebruik te maken van geldboetes die tot een maximum zijn opgevoerd. Die aanbeveling vindt echter weinig weerklank in het feitelijke beleid. Mede vanwege die discrepantie hebben theoretici intensief onderzocht hoe het optimale beleid reageert op wijzigingen in de basisveronderstellingen. Gekeken is onder andere naar de rol van: de ernst van het delict; de kosten van opsporing en bestraffing; de risicohouding van potentiële delinquenten; indirecte kosten van sancties; onvolledige informatie bij delinquenten en bij justitiële autoriteiten; onderscheid tussen algemene en specifieke opsporingsactiviteiten; en type I- en type II-fouten bij de bestraffing. Verder is aandacht besteed aan de aanpak van recidive. Voor een overzicht van deze literatuur, die vrijwel geheel draait om de werking van generale afschrikking, verwijs ik naar Polinsky \& Shavell (2009). Tot eenduidige, praktisch bruikbare recepten heeft het onderzoek niet geleid. Verschillende combinaties van veronderstellingen leiden tot verschillende conclusies zonder dat duidelijk is welke combinatie praktisch het meest relevant is.

Meer recent is in deze literatuur onderkend dat het buiten beschouwing laten van het insluitingseffect van vrijheidsstraffen niet bijdraagt aan het realiteitsgehalte van de conclusies. Miceli (2012) presenteert een dynamische modelvariant, waarin insluiting een aanvulling kan vormen op generale preventie als de afschrikkende werking van het beleid onvoldoende is. Onder het optimale criminaliteitsbeleid zal er in het algemeen nog steeds sprake zijn van 'underdeterrence', hebben geldboetes binnen de grenzen van het mogelijke nog steeds de voorkeur boven vrijheidsstraffen, maar zal de zwaarte van een eventuele vrijheidsstraf hoger uitvallen dan in een model dat alleen gebaseerd is op generale afschrikking.

\subsection{Theorie als basis voor empirisch onderzoek}

In de Popperiaanse wetenschapsfilosofie die door veel economen wordt aangehangen, ligt de betekenis van een theorie uiteindelijk in de empirisch toetsbare voorspellingen die eruit zijn af te leiden. Wordt zo'n hypothese verworpen, dan is dat een teken dat de theorie aanpassing behoeft. ${ }^{7}$ De abstracte, wiskundige theorie van de optimale criminaliteitsbestrijding biedt weinig aanknopingspunten om de empirische relevantie van de veronderstellingen en conclusies vast te stellen. Een belangrijke factor daarbij is dat de theorie zich niet uitlaat over het feitelijke proces van politiek-maatschappelijke besluitvorming. Daarentegen leent Becker's verklaring voor de omvang van de criminaliteit zich wel voor empirisch onderzoek. ${ }^{8}$

\section{Pakkans, strafzwaarte, en andere factoren}

In zijn oorspronkelijke vorm legt Becker's theorie - zie de vergelijkingen (1) t/m (3) hiervoor - een negatief verband tussen de omvang van de criminaliteit enerzijds en de pakkans en de strafzwaarte anderzijds. Verder laat de theorie ruimte voor relevante achtergrondvariabelen. In vervolgstudies is de oorspronkelijke formulering op verschillende punten geamendeerd.

\footnotetext{
7 De wetenschapsfilosofische grondslagen van de economie worden besproken in de bundel van Hausman (2008).

8 Het meeste empirische economische onderzoek maakt gebruik van macrodata. Belangrijke reden, afgezien van de beschikbaarheid van data, is dat het gecombineerde effect van generale afschrikking, insluiting en specifieke preventie zichtbaar gemaakt kan worden. In toenemende mate echter wordt ook gebruik gemaakt van microdata. In plaats van vergelijking (3) is dan vergelijking (2) leidend.
} 
- Brown \& Reynolds (1973) wijzen erop dat opsporing en bestraffing gepaard kunnen gaan met het verlies van de opbrengst van het delict. In zo'n geval moet de berekening van het verwachte nut van delinquent gedrag in vergelijking (1) worden aangepast; in de tweede component in het rechterlid valt de netto opbrengst van crimineel handelen, $C_{j}$, weg. Deze kleine wijziging heeft een belangrijke consequentie voor de afgeleide eigenschappen van vergelijking (3): als de omvang van de criminaliteit gevoeliger blijkt voor veranderingen in de pakkans dan in de strafzwaarte, is dat niet langer een bewijs voor risicominnendheid, het kan ook optreden onder risico-aversie.

Een variant is te vinden bij Mungan \& Klick (2015) die opmerken dat delinquenten het genot van de opbrengst van hun illegale activiteiten soms moeten uitstellen totdat hun straf is uitgezeten. In de tweede component in het rechterlid van vergelijking (1) moet dan rekening worden gehouden met de tijdsvoorkeur. Daarbij gaan economen ervan uit dat het welbevinden van mensen sterker wordt beïnvloed door baten en kosten in het heden dan in de toekomst. ${ }^{9}$ Ook deze aanpassing beïnvloedt de afgeleide eigenschappen van vergelijking (3) en maakt de omvang van de criminaliteit gevoeliger voor veranderingen in de pakkans dan in de strafzwaarte.

- $\quad$ In vergelijking (1) staat $f_{j}$ voor de nadelige gevolgen van opsporing en bestraffing. Daarbij moet natuurlijk eerst en vooral gedacht worden aan de strafrechtelijke sanctie. Maar er zijn ook tal van andere materiële en immateriële kosten in het geding, zoals tijdverlies vanwege aanhouding en verhoor, kosten van juridische bijstand, gevoelens van schaamte, reputatieschade en baanverlies. Zie bijvoorbeeld Carr-Hill en Stern (1979). Om onjuiste interpretaties te voorkomen $\operatorname{kan} f_{j}$ beter worden gesplitst in een strafrechtelijke en een nietstrafrechtelijke component, zeg, $f_{j}^{s}$ en $f_{j}^{n s}$. Zo'n herformulering maakt duidelijk dat een vergroting van de pakkans een dubbel effect heeft: de delinquent wordt niet alleen in versterkte mate geconfronteerd met de lasten van een sanctie, maar ook met de nietstrafrechtelijke gevolgen van opsporing en bestraffing. Dat geeft - wederom - een reden waarom de criminaliteit gevoeliger kan zijn voor een vergroting van de pakkans dan voor een evenredige strafverzwaring. ${ }^{10}$

- In vergelijking (1) komen de legale verdiensten van de potentiële delinquent voor, $L_{j}$, maar lijkt er geen aparte rol te zijn weggelegd voor de loonvoet of eventuele werkloosheid. Dat verandert als de tijdsbesteding wordt geëxpliciteerd, zoals bij Ehrlich (1973). Wanneer het voorbereiden en plegen van een delict tijd vraagt, gaat dat ten koste van andere activiteiten - legaal werk, vrije tijd - zodat opportunity costs in de afweging gaan meespelen. Bovendien zijn die opportunity costs, en dus de afweging, anders als de betrokkene werkloos is. Een en ander kan zichtbaar worden gemaakt door $C_{j}$, de netto opbrengst van crimineel handelen, nader uit te splitsen. Zeg: $C_{j}=G_{j}-w t_{j}^{i}$, waarbij $G_{j}$ de bruto opbrengst is van het delict en $w t_{j}^{i}$ de opportunity costs doordat de betrokkene in de illegale uren $t_{j}^{i}$ het reguliere uurloon $w$ misloopt (voor zover hij niet werkloos is).

- Block \& Heineke (1975) voegen daaraan toe dat ook de invloed van normen en waarden zichtbaar gemaakt kan worden. Als delinquent gedrag moreel-ethisch een inbreuk vormt op het persoonlijke welbevinden van de dader, kan de netto opbrengst van een delict worden weergegeven als $C_{j}=G_{j}-w t_{j}^{i}-H_{j}$, waarbij $H_{j}$ de 'preference for honesty' weergeeft.

\footnotetext{
$9 \quad$ Om de afnemende bijdrage van baten en kosten in de toekomst aan het momentane welbevinden weer te geven, maken economen gebruik van een discontovoet.

10 De economische literatuur heeft inmiddels ook oog voor een mogelijke samenhang tussen de instrumentele, afschrikkende werking van sancties en hun normerende rol. Zie Mulder (2017). Doordat sancties tot uitdrukking brengen wat maatschappelijk goed en fout wordt geacht, kunnen ze bijdragen aan opbouw en versterking van normen en waarden. Dat suggereert een correlatie tussen $f_{j}^{s}$ en $f_{j}^{n s}$.
} 
Samengevat leiden de amenderingen tot de conclusie dat de pakkans hoe dan ook een negatief effect heeft op de omvang van de criminaliteit, en dat de strafzwaarte naar alle waarschijnlijkheid en ongeacht de risicohouding een kleiner effect heeft dan de pakkans.

De effecten van de loonvoet, de werkloosheid en het legale inkomen liggen theoretisch niet eenduidig vast. In eerste instantie zullen een hoger uurloon en een geringere werkloosheid crimineel gedrag minder aantrekkelijk maken; de opportunity costs nemen immers toe. Economen spreken in dat verband van een substitutie-effect. Maar tegelijk is het denkbaar dat er een inkomenseffect optreedt in tegengestelde richting. Wanneer mensen over een ruimere financiële positie beschikken, zouden ze meer dan voorheen geneigd kunnen zijn om eens een gokje te wagen; en dat zou een stimulans kunnen geven aan crimineel gedrag. ${ }^{11}$ Empirisch onderzoek moet dan uitsluitsel geven.

Verder wordt onderstreept dat de economische theorie van crimineel gedrag veelomvattend is. Alle factoren, materieel en immaterieel, die relevant kunnen zijn voor de kosten-batenafweging van de potentiële delinquent verdienen de aandacht. Denk bijvoorbeeld ook aan de opbrengsten en kosten van het delict zelf en aan de niet-strafrechtelijke kosten van eventuele aanhouding en veroordeling.

\section{Rationeel gedrag, of toch niet?}

Ondanks alle verzekeringen dat de economische benadering niet staat of valt met perfect geïnformeerde en volledig bewust en foutloos beslissende actoren, is de kritiek op de rationele-keuze-veronderstelling niet verstomd. Begrijpelijk, want uit psychologische experimenten komt naar voren dat de mens bij afwegingen in onzekerheid systematische fouten maakt; zie Kahneman (2011) voor een overzicht. Zo onderschat de mens de gevolgen van negatieve gebeurtenissen (overoptimisme). Verder waardeert de mens uitkomsten niet als zodanig, maar op grond van de verandering ten opzichte van een referentiepunt (prospect theorie). Het vakgebied van de gedragseconomie (behavioral economics) onderzoekt de consequenties van een en ander. Overoptimisme kan bijvoorbeeld leiden tot een overschatting van de opbrengsten van delinquent gedrag; tegelijk wordt de delinquent mogelijk minder voorzichtig waardoor de feitelijke pakkans hoger uitvalt. De prospect theorie suggereert dat kleine pakkansen mogelijk een sterker effect hebben dan eerder gedacht, en dat het verlengen van op zich al zware vrijheidsstraffen maar weinig extra zoden aan de dijk zet. Zie verder Jolls (2005) en McAdams \& Ulen (2009). Vooralsnog lijken economen ervan uit te gaan dat de nieuwe inzichten geen revolutie betekenen, maar prima ingebouwd kunnen worden in de bestaande theorieën als ze eenmaal voldoende zijn uitgekristalliseerd. Een uitgewerkte alternatieve theorie is in ieder geval nog niet beschikbaar. ${ }^{12}$

\section{Interactie met slachtoffers}

Ehrlich (1996) wijst erop dat de reactie van (potentiële) slachtoffers in Becker's analyse ten onrechte buiten beeld blijft. Burgers en bedrijven nemen meer preventieve maatregelen (beter hang- en sluitwerk, vermijdend gedrag, buurtpreventie enz.), naarmate de kans op slachtofferschap toeneemt. Dat zet automatisch een rem op de criminaliteit, geheel los van overheidsinterventies. De interactie tussen (potentiële) daders en slachtoffers kan worden geanalyseerd met behulp van de speltheorie, een tak van de wiskunde waarin de strategische interactie tussen mensen centraal staat. ${ }^{13}$ Zie ook Cressman, Morrison \& Wen (1998). Interessant is dat het preventieve gedrag van slachtoffers de mogelijkheden van

\footnotetext{
11 Economen nemen vaak aan dat mensen worden gekenmerkt door een afnemende absolute risico-aversie. Zie verder Eide (2000).

12 Van Winden \& Ash (2012) ondernemen een eerste poging om cognitieve en emotionele factoren in de besluitvorming te combineren.

13 Ehrlich zelf spreekt van een 'marktmodel', een ongelukkige term.
} 
overheidsbeleid relativeert. Immers, als de overheid de criminaliteitsbestrijding met succes ter hand neemt, zullen burgers en bedrijven concluderen dat hun preventieve maatregelen op een zachter pitje kunnen.

\section{Gelegenheid}

De criminele keuzebeslissing bij Becker (1968) vooronderstelt dat er gelegenheid is om een delict te plegen. Nagin e.a. (2015) presenteren een uitgebreider model, waarin potentiële delinquenten op zoek gaan naar interessante doelwitten. Verondersteld wordt dat doelwitten, gegeven hun specifieke kenmerken, verschillen in de kans dat een delict wordt opgelost. Doelwitten met een voldoende lage opsporingskans kunnen dan voor een delinquent, bij overigens gelijke opbrengsten, kosten en strafzwaarte, interessant zijn om ter hand te nemen; doelwitten met een hogere opsporingskans zullen ongemoeid blijven. Nagin e.a. laten vervolgens zien dat hun model kan worden gebruikt om de werking van verschillende politiestrategieën te onderzoeken. Ze benadrukken dat een effectievere politie-inzet heel wel gepaard kan gaan met een daling van het feitelijke opsporingspercentage; immers, de delicten die overblijven zijn de moeilijkste om op te lossen. Het hoeft ook geen verrassing te zijn als de door burgers gepercipieerde pakkans aanzienlijk hoger is dan het feitelijke opsporingspercentage; immers, de gemiddelde gepercipieerde pakkans verwijst mede naar potentiële delicten die uiteindelijk achterwege blijven uit vrees voor (de relatief hoge kans op) strafrechtelijke repercussies.

\section{Dynamische modellen. Aandacht voor preventie en resocialisatie}

Becker (1968) analyseert het criminele keuzegedrag in een statische setting. Factoren en processen waarbij de tijd een rol speelt blijven onderbelicht. Denk in dat verband aan de tijdshorizon van potentiële delinquenten, tot uiting komend in de manier waarop ze toekomstige baten en kosten disconteren, aan de mogelijke intertemporele substitutie van criminele activiteit, en aan de ontwikkeling van sociale normen en van human capital. Mede als gevolg van die statische setting krijgt aan de beleidskant de generale afschrikking van oudsher meer aandacht dan preventie en resocialisatie.

McCrary (2010) bouwt Becker's verklaring van crimineel gedrag uit tot een dynamisch model; zie ook Lee \& McCrary (2017). In dat model is de omvang van de criminaliteit groter, naarmate de tijdshorizon van potentiële delinquenten korter is; lange gevangenisstraffen werken nu eenmaal niet erg afschrikwekkend als delinquenten weinig gewicht hechten aan baten en kosten in de (verdere) toekomst. Verder kan een toename van de verwachte netto opbrengst van delinquent gedrag twee tegenstrijdige effecten hebben: enerzijds wordt criminaliteit lonender, anderzijds kan aanhouding en vrijheidsstraf betekenen dat mogelijk nog lonender doelwitten in de toekomst onbereikbaar worden.

Flinn (1986) presenteert een model waarbij de tijdsverdeling tussen legale en illegale activiteiten in opeenvolgende perioden wordt onderzocht. De delinquent die wordt gepakt kan voor de duur van de vrijheidsstraf geen nieuwe delicten plegen. Tegelijk verdwijnt hij ook van de arbeidsmarkt, waardoor de opbouw van zijn human capital (ervaring, on-the-job scholing) stokt en zijn toekomstig loon minder hoog uitvalt. De persoon die op enig moment besluit meer tijd te steken in criminele activiteiten, krijgt dus te maken met diverse kostenposten: (i) het mislopen van legale inkomsten; (ii) een geringere opbouw van human capital waardoor de legale inkomsten in de toekomst lager uitvallen; (iii) een grotere kans op een vrijheidsstraf doordat hij meer blootstaat aan opsporing; en (iv) een vergrote kans op lagere legale inkomsten in de toekomst doordat hij tijdens zijn vrijheidsstraf minder human capital opbouwt. Een additionele kostenpost treedt op als bij recidive zwaardere straffen worden opgelegd. Het model blijkt in staat om het leeftijdsprofiel van delinquenten te reproduceren. Lochner (2004) en Sickles \& Williams (2008) breiden het model verder uit door investeringen 
in opleiding en de rol van normen en waarden (wroeging, reputatie) toe te voegen. In deze setting is het denkbaar dat preventieprogramma's gericht op risicojongeren uiteindelijk meer effect hebben dan vrijheidsstraffen of resocialisatieprojecten.

\section{Sterke en zwakke punten}

Tot slot doe ik een poging om de balans op te maken.

Een zwak punt vanuit criminologisch perspectief is ongetwijfeld dat de economische benadering geen poging doet de 'root causes' van menselijk gedrag te achterhalen. In samenhang daarmee hebben economen ook niet de pretentie dat ze het individuele gedrag van afzonderlijke actoren kunnen verklaren of voorspellen. Economen vinden het vanzelfsprekend dat preferenties van personen kunnen verschillen; maar ze gaan ervan uit dat die preferenties en hun onderlinge verschillen (min of meer) stabiel zijn, zodat ze zich in hun onderzoek kunnen concentreren op de gevolgen van veranderingen in omstandigheden en prikkels. Voor hen is dat juist een sterk punt omdat het het kader biedt waarin de aandacht zich kan richten op sociale interacties en op de mogelijkheden voor beleidsinterventies. Overigens moet de stabiliteit van de preferenties niet al te absoluut worden genomen, het 'min of meer' staat er niet voor niets. Geleidelijke veranderingen in preferenties onder invloed van de werking van structurele factoren kunnen zich goed lenen voor inpassing in economische analyses. Denk aan verschuivingen in normen en waarden (wroeging, schaamte) onder invloed van beleidswijzigingen en sociale interactie.

Een sterk punt voor economen is de rationele-keuze-veronderstelling, omdat deze een gemeenschappelijk kader biedt voor alle theorievorming. Toepassing van de rationele-keuzeveronderstelling zorgt er volgens Becker $(1968,176)$ voor "that criminal behavior becomes part of a much more general theory and does not require ad hoc concepts of differential association, anomie, and the like." De rationele-keuze-veronderstelling is tegelijk een zwak punt. Want het past dan wel binnen de theorie dat mensen vanwege de kosten van het vergaren en verwerken van gegevens onvolledig geïnformeerd zijn en dat ze een belangrijk deel van hun beslissingen niet bewust nemen; problematisch blijft dat ze systematische fouten maken, met name in situaties van onzekerheid. De verwachting dat die systematische denkfouten geïncorporeerd kunnen worden in de bestaande theorievorming, moet nog worden waargemaakt. ${ }^{14}$

De theorievorming van economen heeft een gemeenschappelijk kader, in de vorm van de rationele-keuze-veronderstelling. Die verbindende lijn door alle theorie is op zich een sterk punt. Toch heeft dat in de literatuur vooralsnog niet geresulteerd in één allesomvattend model, maar in een verzameling verwante deelmodellen voor afzonderlijke onderzoeksvragen. Zo biedt bijvoorbeeld de theorie omtrent het optimale criminaliteitsbeleid weinig aanknopingspunten voor empirische toetsing. Omgekeerd biedt de aan de empirie gerelateerde literatuur vooralsnog onvoldoende basis voor het uitstippelen van een optimaal criminaliteitsbeleid.

Vanwege de directe beleidsrelevantie heeft de economische theorie van misdaad en straf veel aandacht besteed aan de generaal-afschrikkende werking van pakkans en strafmaat. Dat heeft op zich, sterk punt, interessante kennis opgeleverd over de factoren die medebepalend zijn voor effectiviteit en efficiëntie van de inzet van politiemiddelen en de duur van vrijheidsstraffen. Door die nadruk op de generaal-afschrikkende werking was er echter lange tijd minder aandacht voor de betekenis van insluiting en specifieke preventie, en voor de mogelijkheden van resocialisatie en preventie. Dat betekende dat in de theorievorming kon worden volstaan met statische modellen. Dynamische modellen zijn daarom nog onderontwikkeld.

\footnotetext{
14 Merk op dat in het empirische onderzoek de systematische denkfouten automatisch, maar impliciet,
} ingesloten zitten in de bevindingen. 
Resteert de vraag of de zwakke punten voldoende grondslag bieden om de economische theorie van misdaad en straf af te serveren als irrealistisch en onbruikbaar. Economen denken van niet omdat het veld op tal van punten in beweging is en een hoopvol perspectief biedt op (nog) beter. Bovendien legt de theorie de basis voor veel en vruchtbaar empirisch onderzoek. Zo wordt er op basis van de rationele-keuze-theorie onderzoek gedaan naar de determinanten van crimineel gedrag in het algemeen (zie bijvoorbeeld Loughran e.a., 2016), maar ook naar specifieke thema's zoals de determinanten van de gepercipieerde pakkans (Lochner, 2007), de invloed van de economische omstandigheden (Gould e.a., 2002; Machin \& Meghir, 2004), de betekenis van opleiding (Lochner \& Moretti, 2004) en de rol van normen en waarden (Kroneberg e.a., 2010). Ook wordt er vanwege de directe beleidsrelevantie intensief gekeken naar de betekenis van de inzet van politiemiddelen en het opleggen van gevangenisstraffen (zie voor een recent overzicht Chalfin \& McCrary, 2017). Naast de generaal afschrikkende werking (Bell e.a., 2014) komen daarbij tegenwoordig ook het insluitingseffect (Owens, 2009) en de mogelijk contraproductieve invloed van specifieke preventie (Green \& Winik, 2010; Kuziemko, 2013) aan bod. Verder wint in het verlengde van het empirische onderzoek het instrument van de maatschappelijke kosten-batenanalyse aan betekenis bij de voorbereiding en evaluatie van strafrechtelijke interventies (zie bijvoorbeeld http://www.wsipp.wa.gov/). In dat verband is er ook nadrukkelijk aandacht voor de vraag of en op welke manier een beleid gebaseerd op preventie en resocialisatie een bruikbaar alternatief zou kunnen vormen voor een beleid van repressie (Aos \& Drake, 2010). ${ }^{15}$

\section{Literatuur}

Aos, S. \& Drake, E. (2010). WSIPP's benefit-cost tool for states. Examining policy options in sentencing and corrections. Olympia (WA): Washington State Institute for Public Policy.

Beccaria, C. (1764). Dei delitti e delle pene. Geraadpleegde versie: R. Bellamy (ed.). On crimes and punishments and other writings. Cambridge: Cambridge University Press, 1995, 1-113.

Becker, G.S. (1968). Crime and punishment: An economic approach. Journal of Political Economy, 76(2), 169-217.

Bell, B., Jaitman, L. \& Machin, S. (2014). Crime deterrence: Evidence from the London 2011 riots. Economic Journal, 124(2), 480-506.

Bentham, J. (1789). An introduction to the principles of morals and legislation. Geraadpleegde versie: Amherst NY: Prometheus Books, 1988.

Block, M.K. \& Heineke, J.M. (1975). A labor theoretic analysis of the criminal choice. American Economic Review, 65(3), 314-325.

Brown, W.W. \& Reynolds, M.O. (1972). Crime and "punishment”: Risk implications. Journal of Economic Theory, 6(5), 508-514.

Carr-Hill, R.A. \& Stern, N.H. (1979). Crime, the police and criminal statistics. London: Academic Press.

Chalfin, A. \& McCrary, J. (2017). Criminal deterrence: A review of the literature. Journal of Economic Literature, 55(1), 5-48.

Cressman, R. Morrison, W.G. \& Wen, J. (1998). On the evolutionary dynamics of crime. Canadian Journal of Economics, 31(5), 1101-1117.

Ehrlich, I. (1973). Participation in illegitimate activities: A theoretical and empirical investigation. Journal of Political Economy, 81(3), 521-565.

Ehrlich, I. (1996). Crime, punishment, and the market for offenses. Journal of Economic Perspectives, 10(1), 43-67.

15 Zie Van Velthoven (2017) voor een uitgebreider overzicht van het empirische onderzoek naar crimineel gedrag en de concrete toepassingen van maatschappelijke kosten-batenanalyse, in binnen- en buitenland. 
Eide, E. (2000). Economics of criminal behavior. In: B. Bouckaert \& G. de Geest (eds.). Encyclopedia of law and economics. Volume V: The economics of crime and litigation. Cheltenham \& Northampton MA: Edward Elgar, 345-389.

Fleisher, B.M. (1963). The effect of unemployment on juvenile delinquency. Journal of Political Economy, 71(6), 543-555.

Flinn, C. (1986). Dynamic models of criminal careers. In: A. Blumstein et al. (eds.). Criminal careers and 'career criminals', vol. 2. Washington DC: National Academy Press, 356379.

Gould, E.D., Weinberg, B.A. \& Mustard, D.B. (2002). Crime rates and local labor market opportunities in the United States: 1979-1997. Review of Economics and Statistics, 84(1), 45-61.

Green, D.P. \& Winik, D. (2010). Using random judge assignments to estimate the effects of incarceration and probation on recidivism among drug offenders. Criminology, 48(2), 357387.

Hausman, D.M. (ed.) (2008). The philosophy of economics. An anthology. Cambridge: Cambridge University Press.

Jolls, C. (2005). On law enforcement with boundedly rational actors. In: F. Parisi \& V. Smith (eds.). The law and economics of irrational behavior. Stanford CA: Stanford University Press, 268-286.

Kahneman, D. (2011). Thinking, fast and slow. New York: Farrar, Straus and Giroux.

Kaplow, L. \& Shavell, S. (2002). Fairness versus welfare. Cambridge MA \& London: Harvard University Press.

Kroneberg, C., Heintze, I. \& Mehlkop, G. (2010). The interplay of moral norms and instrumental incentives in crime causation. Criminology, 48(1), 259-294.

Kuziemko, I. (2013). How should inmates be released from prison? An assessment of parole versus fixed-sentence regimes. Quarterly Journal of Economics, 128, 371-424.

Lee, D.S. and McCrary, J. (2017). The deterrence effect of prison: Dynamic theory and evidence. Advances in Econometrics, 38, 73-146.

Lilly, J.R., Cullen, F.T. \& Ball, R.A. (2015). Criminological theory. Context and consequences. Los Angeles CA: SAGE Publications, 6th ed.

Lochner, L. (2004). Education, work, and crime: A human capital approach. International Economic Review, 45(3). 811-843.

Lochner, L. (2007). Individual perceptions of the criminal justice system. American Economic Review, 97(1), 444-460.

Lochner, L. \& Moretti, E. (2004). The effect of education on crime: Evidence from prison inmates, arrests, and self-reports. American Economic Review, 94(1), 155-189.

Loughran, T.A., Paternoster, R., Chalfin, A. \& Wilson, T. (2016). Can rational choice be considered a general theory of crime? Evidence from individual-level panel data. Criminology, 54(1), 86-112.

Machin, S. \& Meghir, C. (2004). Crime and Economic Incentives. Journal of Human Resources, 39(4), 958-979.

McAdams, R.H. \& Ulen, T.S. (2009). Behavioral criminal law and economics. In: N. Garoupa (ed.). Criminal law and economics. Cheltenham \& Northampton MA: Edward Elgar, 403436.

McCrary, J. (2010). Dynamic perspectives on crime. In: B.L. Benson \& P.R. Zimmerman. Handbook on the economics of crime. Cheltenham \& Northampton (MA): Edward Elgar, 82-105.

Miceli, T.J. (2012). Deterred or detained? A unified model of criminal sanctions. Review of Law and Economics, 8(1), 1-20.

Mulder, L.B. (2017). When sanctions convey moral norms. European Journal of Law and 
Economics, doi 10.1007/s10657-016-9532-5.

Mungan, M.C. \& Klick, J. (2015). Discounting and criminals' implied risk preferences. Review of Law and Economics, 11(1), 19-23.

Nagin, D.S., Solow, R.M. \& Lum, C. (2015). Deterrence, criminal opportunities, and police. Criminology, 53(1), 74-100.

Owens, E.G. (2009). More time, less crime? Estimating the incapacitative effects of sentence enhancements. Journal of Law and Economics, 52(3), 551-579.

Piquero, A.R. (ed.) (2016). The handbook of criminological theory. Chichester: John Wiley \& Sons.

Polinsky, A.M. \& Shavell, S. (2009). Public enforcement of law. In: N. Garoupa (ed.). Criminal law and economics. Cheltenham \& Northampton MA: Edward Elgar, 1-59.

Rodrik, D. (2015). Economics rules. The rights and wrongs of the dismal science. New York \& London: W.W. Norton \& Company.

Sickles, R.C. \& Williams, J. (2008). Turning from crime: A dynamic perspective. Journal of Econometrics, 145, 158-173.

Velthoven, B.C.J. van (2017). Economie van misdaad en straf. Den Haag: Boom criminologie, 2e druk.

Winden, F. van \& Ash, E. (2012). On the behavioral economics of crime. Review of Law and Economics, 8(1), 181-213. 